\title{
THE APPLICATION OF AUTHENTIC ASSESSMENT IN CHEMISTRY CURRICULUM STUDIES
}

\author{
Beta Febriana and Widinda Arlianty \\ Department of Chemistry Education, Islamic University of Indonesia, Indonesia
}

\begin{abstract}
One of the growing issues in Indonesia is changing curriculum. Nowadays, most of high school using two different curriculum. Teacher candidates must be understand and differentiate between that two curriculum was applied. The purpose of the study was to investigate the effect of authentic assessment on the teacher candidates in Chemistry Education. This study was used Classroom Action Research using two cycles of learning. The sample were teacher candidates of Chemistry Education $4^{\text {th }}$ semester in academic year 2016/2017. The learning approach used is Contextual Teaching and Learning. Data collection techniques used is testing method and nontesting methods. The test method consists of tests for cognitive, on the other hand, the non-test methods using a Likert scale questionnaire and an observation sheet. The tool of authentic assessment consisted of reviewing aspects of knowledge, attitudes, and self-efficacy and peer assessment. The results showed that student achievement increased from the first to second cycles. In the cognitive aspect, the students' scores increased from $62.00 \%$ to $81.67 \%$; in aspects of the attitude that consists of attitude assessment, self-efficacy, and peer assessment in the first cycle of 77.04\%; $75.71 \% ; 72.57 \%$, while in the second cycle of $79.07 \% ; 77.62 \% ; 73.61 \%$ respectively.
\end{abstract}

Keywords: Authentic Assessment, Contextual Teaching and Learning, Chemistry Curriculum Studies

\section{Introduction}

The subject Chemistry Curriculum Studies is one of the compulsory subjects are held on the fifth semester with two credits of semester. This course discusses the components of the curriculum in a national education system. Indonesian curriculum education includes curriculum structure which is then presented in the form of subsequent syllabus and then the syllabus used as a reference in designing of Lesson Plan. Learning gains subjects on this subject are that students have an understanding and ability to develop chemistry curriculum in school and understand the urgency of character education in school chemistry curriculum studies.

The study subjects of this curriculum will be taught to students of Chemistry Education Department on fifth semester of 2014. The character of this students is passive to the learning process. Learning system that tends to be a teacher-centered result in students only receive knowledge, notes and even tend to memorize lessons. Learning materials are only learned by wrote will be easier to be forgotten by the students because the materials are considered to be memorable. Score obtained was also unsatisfactory so we need methods that can make students actively in learning activities. One is to apply methods that are student-centered learning.

Student of Chemistry Education Program graduates are expected to become competent in the field of education one of them to be competent in analyzing the content/structure of the curriculum where the curriculum is the spirit of the national education system. In analyzing the structure of the curriculum, students can directly observe the implementation of the curriculum in a school. The process of student assessment based solely on the score of mid-semester test (MST) and the final-semester test (FST) has not been able to assess the overall activity of students in the learning process. In fact, the learning process that is student-centered involve thinking students skills are hands on and minds on. Assessment to assess overall student activity is authentic assessment. This assessment consists of authentic assessment itself and portfolio assessment. All results of the students tasks are well documented, neat, easy to read and traceable through the assessment process.

The process of learning is conducted should be accompanied by the process of assessment/appraisal capable of assessing student activity with truth. A proper assessment appropriates to assess the process of student activities

Corresponding Author: Beta Febriana/ betawulanfebriana@uii.ac.id 
in the course curriculum is the Authentic Assessment. Authentic is a process of collecting, reporting and using information about student learning outcomes by applying valuation principles, the implementation of sustainable, evidence is authentic, accurate, and consistent as public accountability (Depdiknas, 2009). Based on the above mentioned backgrounds, it can be the formulation of the problem, namely how the implementation of assessing by authentic assessment in Chemistry Curriculum Studies.

\section{Literature Review}

Authentic assessment is the process of gathering information by teachers/lecturers about the progress and achievement of learning undertaken by learners through a variety of techniques are able to express, to prove, or demonstrate precisely that the learning objectives have been completely overcome and accomplished (Nurhadi, 2004). Data were collected through assessments not to seek information about student learning. True learning should be emphasized in order to help students to be able to learn and not emphasized in obtaining as much information at the end of the study period (Nurhadi, 2004).

Authentic assessment concerned with the assessment process and results at once. Thus, the entire look of the students in a series of learning activities can be assessed objectively, it is, and not solely based on the final result (product). Authentic assessment emphasizes the ability of learners to demonstrate their knowledge in a real and meaningful. The assessment activities are not just ask or tapped the knowledge that has been known to learners, but also the real performance of the knowledge that has been mastered. As Mueller (2006) stated authentic assessment is a form of assessment in which students are asked to perform real-world tasks that demonstrate meaningful application of essential knowledge and skills. Authentic assessment can form a task for the students to showcase their knowledge, skills and attitude, and an assessment criteria or rubric which will be used to assess performance based on the task.

Self-efficacy is defined as a person's judgment about his/her ability to achieve the desired level of performance or determined, which will affect the next action (Bandura, 1997). According to Zimmerman (2000), selfefficacy is a personal judgment about a person's ability to organize and implement the work program in achieving its intended purpose, and he tried to assess the level, generality and strength of all the activities and contexts. Zimmerman added that self-efficacy beliefs will keep students motivated to learn through the use of self-regulation as a process of goal setting, self-monitoring, self-evaluation, and strategies used. Additionally, it will determine how much effort it does, how long he stayed when in trouble, and how flexible the unfortunate situation. Noer (2012) stated that the greater a person's self-efficacy, the greater the effort, perseverance, and flexibility. Self-efficacy also affects the mindset and emotional reactions. A person with low self-efficacy will give up easily, tend to become stressed, depressed, and have a narrow vision of what is best to resolve the problem. While high self-efficacy, will help a person in creating a sense of calm in the face of a difficult problem or activity.

Peer-rating is an assessment that involves the students to assess the quality of their work. Rating peer requires other students to provide feedback on the score or the performance of their friends or their products based on a criteria who have made the criteria that have been made with them (Kartono, 2011). Some advantages of rating peers, among others: 1) to improve learning outcomes, 2) to improve collaborative learning through feedback from peers, 3) Students can help the theme in understanding and studying them and feel more comfortable in the learning process, and 4) students can comment on their performance. A peer assessment results similar to the results of teacher assessment (Falchinov \& Goldfrich, 2000) and a common understanding between the assessor in understanding the assessment criteria at peers.

\section{Research Methods \\ Research design}

The design of this research is Classroom Action Research by Kemmis and Mc Taggart by using two cycles. The first cycle is conducted before the mid-semester test (MST) while the second cycle is implemented after midsemester test (MST). Furthermore, improving the learning process by using the mid-semester test (MST) and the final-semester test (FST) results. The design of this research presented in Fig 1 below. 


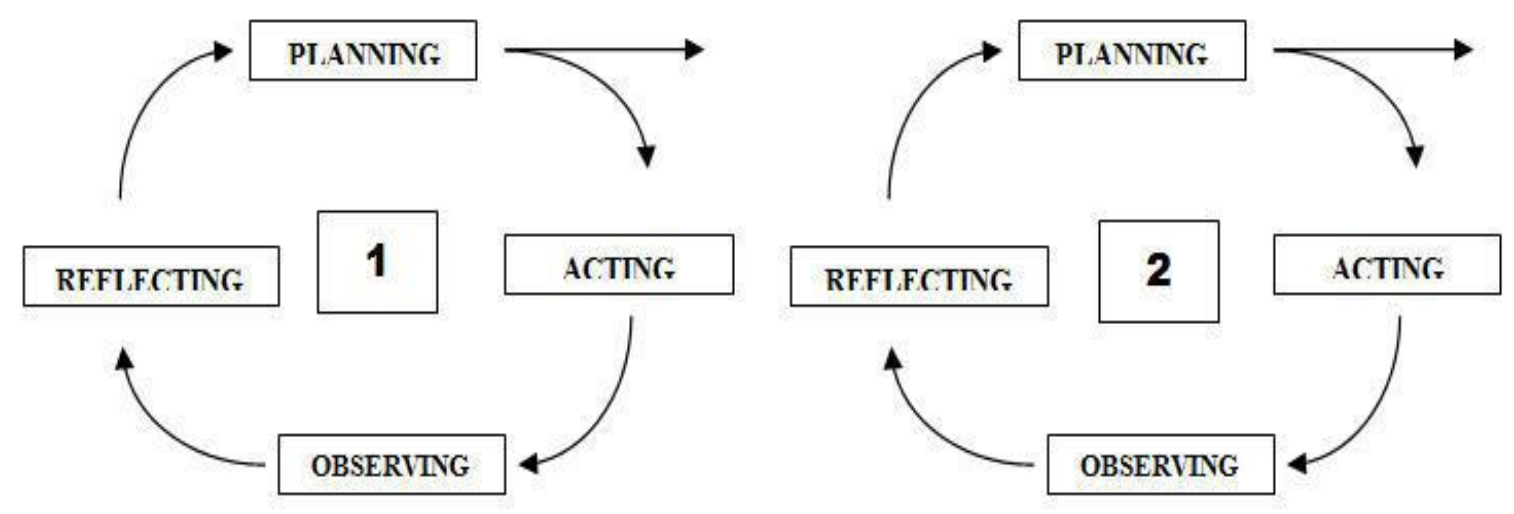

Figure 1. Design of the research

\section{Research Subjects}

Subjects in this study were students of Chemistry Education Program in fifth semester 2014 class of nine. Assessments have been conducted which consisted of the test assessment analyzed using quantitative analysis, whereas the non-test assessment using qualitative analysis.

Research Instruments

Data collection research using assessment of aspects of knowledge, attitudes, self-efficacy and peers. Instruments which are used in the form of test and non-test sheets.

1. Test sheet

- Cognitive aspect (knowledge)

2. Non-test sheet

- Affective aspect (attitude) : questionnaire

- Self-efficacy : questionnaire

- Peer assessment : observation sheet

Assessment for cognitive aspect taken from assessment through MST and FST while assessment for affective aspect and self-efficacy obtained by questionnaire. Peer assessment obtained from observationa sheet who filled by students. The items used to assess of self-efficacy and peer assessment are shown in Table 1 and Table 2.

Table 2 Aspect of Self-efficacy Assessment

\begin{tabular}{l}
$\begin{array}{l}\text { Aspect } \\
\text { efficacy }\end{array}$ of Self- $\quad$ Indicator of Self-efficacy \\
\hline
\end{tabular}

Level

The student's belief in his ability to do planning and self-regulation

The student's belief in his ability to complete learning tasks that have varying degrees of difficulty in learning

Strength

The students' belief in their effort ability in realizing the expected learning objectives 


Aspect of Self- $\quad$ Indicator of Self-efficacy
efficacy

The student's belief in his ability to persevere in the efforts undertaken to achieve the learning objectives

Generality

The student's belief in his ability to make prior experiences as a force in achieving learning achievement

The students' belief in their ability in the lesson is a reliable skill for success in various situations/tasks.

Table 2 Aspect of Peer Assessment

Aspect of Peer Assessment $\quad$ Indicator of Peer Assessment

Make a plan with full of responsibility Diligently plotting the observed object

Determine details of aspects to be observed closely

Carry out the task with full of Observe the object seriously responsibility

Gather assignments just in time

Carry out the task with full of honesty Carry out the observation task seriously

Keeping track of factual observations

\section{Data Analysis and Results}

Instrument Validation Results

Validation of research instrument by two judgement experts. The results of the validation instrument of cognitive assessment, affective assessment, self-efficacy assessment and peer assessment using the formula Gregory presented in Table 3 below.

Table 3. Summary of Content Validity Result of Authentic Assessment

\begin{tabular}{lccc}
\multicolumn{1}{c}{ Variable } & $\begin{array}{c}\text { The number of } \\
\text { Indicator }\end{array}$ & CV & Conclusion \\
\hline Cognitive Instrument & 12 & 0,95 & Analysis can be \\
Affective Instrument & 20 & 0,82 & 0,88 \\
continued
\end{tabular}




\section{Result of Authentic Assessment}

Results of this research was obtained from several assessment (authentic asessment). The results of such assessment have been presented in Table 4 and Figure 1 below.

Table 4. Result of Authentic Assessment in Cycle I and Cycle II

\begin{tabular}{lcc}
\hline \multicolumn{1}{c}{ Assessment Aspect } & $\begin{array}{c}\text { Cycle I (\%) } \\
\text { (MST) }\end{array}$ & $\begin{array}{c}\text { Cycle II (\%) } \\
\text { (FST) }\end{array}$ \\
\hline Cognitive & 62,00 & 81,67 \\
Affective & 77,04 & 79,07 \\
Self-efficacy & 75,71 & 77,62 \\
Peer Assessment & 72,57 & 73,61 \\
\hline
\end{tabular}



Figure 1. Result of Authentic Assessment in Cycle I and Cycle II

\section{Result and Discussion}

Planning

This stage consists efforts in making assessment instruments in the form of test and non-test as well as the format used by the students for task/project is given. The instrument has been validated/reviewed by judgement experts in the field. Based on the review, the overall research instrument used to get the category " Analysis can be continued "

Acting

At this stage contains learning activities that have been adapted to syllabus and Course Outline (CO) is created.

Observing

The learning process is done by discussion and question and answer. Discussion and question and answer session is conducted in groups.

Assessment conducted at this stage is the peer assessment. This assessment uses observation sheets where one student by another student assessed objectively. Then the student was assessed also assesses his/her class in turn. In this case, the student assessed by eight of his friends. This assessment can help lecturers to conduct a comprehensive assessment by lecturer limitations in observing all the students in the limited time.

Based on Figure 1, the results of peer assessment in the first cycle of $72.51 \%$. The results of peer assessment in the second cycle increased by $1.04 \%$. The increase was triggered because the student is more responsible for 
what they do. Based on the findings showed that students who scored low in the first cycle, the second cycle they has increased the score by their friends. On assignment held on this second cycle is continuous so that if a student left behind one of the tasks, the tasks that otherwise would not be done. This has encouraged students to be more aware of the importance of a given task.

Furthermore, self-efficacy ratings given in the first cycle yield of 75.71\%. J. Strecher, V. et al. cit Noer (2012) said that self-efficacy influences one's choice in setting behavior, the number of their efforts to complete the task, and the length of time they persist in the face of obstacles that self-efficacy affect a person's emotional reaction. Thus, individuals with low self-efficacy against certain tasks more thinking about their personal shortcomings rather than thinking about completing a task, in turn, will hamper the successful completion of the task. Assessment previously granted in this first cycle gives an average score of 77.62. The results obtained in this second cycle rose by $1.91 \%$. Assessment using a questionnaire to assess this themselves brings out the confidence of the individual student if basically they able to perform any task/project is given to the maximum.

Rating attitudes conducted in the first cycle scored of 77.04\%. Rating attitudes uses a questionnaire with Likert scale with four possible answers, namely Strongly Agree, Agree, Disagree and Strongly Disagree. This assessment consists of two statements that are positive statements and negative statements. Competencies expected of votes this attitude is that students are able to behave honestly, discipline, responsibility and teamwork. The assessment carried out on this second cycle. In the first cycle, the results of the assessment of student attitudes achieved by $77.04 \%$, while in the second cycle of this amounted to $79.07 \%$. An increase of $2.03 \%$ happened due to the students here work individually so that raises their individual responsibility which allows an increase in positive attitudes of students in learning.

Knowledge assessment uses assessment tests in the form of mid-semester test (MST). Based on the results of MST, the students average score is $62.00 \%$. Another aspect considered in the learning process is the aspect of knowledge. Aspects of knowledge is assessed using assessment tests in the form of final-semester test (FST). Based on the results, the average score of students reached $81.67 \%$. Results of the assessment of the score of knowledge increased $62.00 \%$ to $81.67 \%$. This significant increase is due to the reflection that has been done at the beginning of the meeting in the second cycle. Reflections on learning in the form of repetition of learning materials bring out new enthusiasm and motivation within the students. Students are more familiar with the repetition of material presented.

Willey \& Gardner (2007) from their research concluded that the self- and peer-assessment positively effect on student learning outcomes, which can improve learning outcomes and increase their desire to learn. In another study Willey \& Gardner (2008) also concluded that the self- and peer-assessment into their facilities in a mutually beneficial receives feedback from their group of friends, as the critical success factors in their study group.

\section{Reflecting}

Reflection phase is about providing feedback during the learning process. Feedback is provided about the learning material that has not been understood by the students. Reflection made after MST takes place so that the faculty and students know the learning achievement indicators which are not yet mastered by students are marked by obtaining a score that is not optimal for each indicator. Furthermore, based on the acquisition of the score, a lecturer repeats material on the indicator that students truly master the concepts given.

At MST results showed that the average score of 62 . Based on the responses of students, they still have not been able to acquire the structural difference between the standards-based curriculum and the curriculum designed in 2013.

\section{Conclusion}

The results pointed out that student achievement increased from the first to second cycles. In the cognitive aspect, the students' scores increased from $62.00 \%$ to $81.67 \%$; in aspects of the attitude that consists of attitude assessment, self-efficacy, and peer assessment in the first cycle of $77.04 \%$; $75.71 \%$; and $72.57 \%$ respectively, while in the second cycle of $79.07 \% ; 77.62 \% ; 73.61 \%$ respectively. 


\section{Acknowledgements}

Authors would like to thank the Academic Development Agency (ADA) Islamic University of Indonesia who has given the opportunity to be one of the recipients of Regular Teaching Grant Program in the first semester of the academic year 2016/2017.

\section{References}

Bandura. 1997. Self-Efficacy: The Exercise of Control. New York: W.H. Freeman and Company

Depdiknas. 2009. Kurikulum TingkatSatuan Pendidikan. Jakarta: Depdiknas.

Falchikov, N dan Goldfinch, J. 2000. Student Peer Assessment in Higher Education: A Meta-Analysis Comparing Peer and Teacher Marks. Review of educational research, 70 (3), 287-322

Kartono. 2011. Efektivitas Penilaian Diri dan Teman Sejawat untuk Penilaian Formatif dan Sumatif pada Pembelajaran Mata Kuliah Analisis Kompleks. Prosiding Seminar Nasional Matematika Prodi Pendidikan Matematika, Universitas Muhammadiyah Surakarta

Masnur, Muslich. 2007. KTSP Pembelajaran Berbasis Kompetensi dan Kontekstual. Jakarta : PT Bumi Aksara

Mueller, John. 2008. Authentic Assessment Toolbox. North Central College http://jfmueller.faculty.noctrl.edu/toolbox/index.htm

Mueller, RJ. 2006. Authentic Assessment. North Central College. http://jonatan.mueller.faculty.noctrl.edu/toolbox/whatisit.htm

Nurhadi. 2004. Kurikulum 2004. Jakarta: Gramedia Widiasarana.

Noer, Sri Hastuti. Self-Efficacy Mahasiswa terhadap Matematika. Seminar Nasional Matematika dan Pendidikan Matematika Jurusan Pendidikan Matematika FMIPA UNY

Willey, K. \& Gardner, AP. 2007. Investigating The Capacity of Self and Peer Assessment to Engage Student and Increase Their Desire to Learn.

Willey, K. \& Gardner, AP. 2008. The Effectiveness of Using Self and Peer Assessment in Short Courses: Does It Improve Learning?. Proceeding of AaeE conference. Tersedia pada http://www.aaee.com.au/ conferences/papers/2008/aaee08_submission_WLCS.pdf.

Zimmerman, B. J. 2000. Self-Efficacy: An Essential Motive to Learn. Contemporary Educational Psychology, $25,82-91$ 